\title{
Hydroponic Greenhouse Production of "Baby" Squash: Selection of Suitable Squash Types and Cultivars
}

\author{
Nicole L. Shaw ${ }^{1}$ and Daniel J. Cantliffe ${ }^{2}$
}

Additional index words. Cucurbita pepo, protected agriculture, soilless culture, specialty vegetable, integrated pest management

\begin{abstract}
SUMMARY. Mini or "baby" vegetables have become increasingly popular items for restaurant chefs and retail sales. Squash (Cucurbita pepo) are generally open-field cultivated where climate, insect, and disease pressures create challenging conditions for growers and shippers who produce and market this delicate, immature fruit. In order to overcome these challenges, in Spring 2003 and 2004, 18 squash cultivars, including zucchini, yellow-summer, patty pan/scallop, and cousa types, were grown hydroponically in a passively ventilated greenhouse and compared for yield of "baby"-size fruit. Squash were graded as "baby" when they were less than 4 inches in length for zucchini, yellow-summer, and cousa types and less than $\mathbf{1 . 5}$ inches diameter for round and patty pan/scallop types. In both seasons, 'Sunburst' (patty pan) produced the greatest number of baby-size fruit per plant, while 'Bareket' (green zucchini) produced the least. The zucchinitypes produced between 16 and 25 baby-size fruit per plant in 2003 . The yellow summer squash-types produced on average 45 baby fruit per plant. The production of the patty pan/scallop types ranged from 50 to 67 baby-size fruit per plant depending on cultivar. The cousa types produced approximately 30 babysize fruit. Total yields were lower in 2004 due to a shortened season. Squash plants will produce numerous high quality baby-sized fruit when grown hydroponically in a reduced pesticide environment of a greenhouse where they can be harvested, packaged, and distributed to buyers daily. The cultivars Hurricane, Raven, Gold Rush, Goldy, Sunray, Seneca Supreme, Supersett, Butter Scallop, Sunburst, Patty Green Tint, Starship, Magda, and HA-187 could be used for hydroponic baby squash production.
\end{abstract}

$\mathrm{D}$ emand for fresh baby vegetables in the United States has been on the rise since the early 1990s when baby carrots (Daucus carota) were popularized in supermarkets. The majority of baby vegetables are marketed as "readyto-eat," for example, gourmet lettuce mixes and microwavable pouches. Baby vegetables have become a favorite with high-end specialty restaurants where gourmet chefs use them as side-dishes and garnishes (Stephens, 1996). A consumer food trends survey in 2000 revealed that many Americans enjoyed the experience of preparing gourmet meals at home (Associated Press, 2003). Consumers have turned their kitchens into social entertainment areas for friends and family to share in exotic

University of Florida, Institute of Food and Agricultural Sciences, Horticultural Sciences Department, P.O. Box 110690, Gainesville, FL 32611-0690.

This research was supported by the Florida Agriculture Experiment Station, and approved for publication as Journal Series R-10470.

${ }^{1}$ Sr. Biological Scientist; to whom reprint requests should

be addressed; email nlshaw@ifas.ufl.edu

${ }^{2}$ Chair/Professor; email djc@ifas.ufl.edu cooking techniques from their favorite restaurant (Bachman, 2002).

While some baby vegetables are specific cultivars that have been bred to have a small size, such as 'King Richard' leek (Allium ampeloprasum) and 'Parmex' carrot, others are merely full-sized vegetables that have been produced under dense planting and harvested early and/or immature as in the case of baby squash (Bachman, 2002; Schmidt, 2003). Many baby carrots are actually pieces of normal-size carrots that are abraded to the smaller size. The early-harvested types of baby vegetables demand more intense production operations to ensure high quality and, in turn, bring a higher financial return to the grower. Baby squash are harvested immature, at a delicate stage when flower blossoms have just opened for pollination and sometimes remain attached (Fig. 1). Attached blossoms or the male flower blossoms are favorable in certain ethnic dishes or can be used as a pocket for certain stuffed appetizers (Sidnam, 2004; Wolford and Banks, 2004).

A clean, undamaged fruit is preferred for packaging, because in the baby vegetable business, damaged fruit or "seconds" cannot be sold (Stephens, 1996). For crops such as tomato (Lycopersicon esculentum), colored pepper (Capsicum annuиm), and cucumber (Cucumis satipus), a superior product can be more easily achieved through production inside a protected structure as compared with open-field cultivation (Cantliffe et al., 2001, 2004). Furthermore, plants may be grown pesticide-free inside a greenhouse, thus increasing the marketing potential of the product. Consumers surveyed in Taiwan were willing to pay $28 \%$ more for vegetables labeled "pesticide-free" than for those conventionally grown with chemical pesticides (Ali et al., 2003).

Squash is grown under protected culture in Mediterranean countries, such as Italy, Spain, and Israel, but commercially it is still grown in the soil using traditional field production techniques [European and Mediterranean Plant Protection Organization (OEPP/ EPPO), 2004; Rouphael et al., 2004]. Currently, detailed information on the production of baby squash is restricted only to those in the private sector and is not available for publication. There are publications describing hydroponic greenhouse production of cucurbit crops such as cucumber (Hochmuth, 2001; Papadopoulos, 1994) as well as others that describe hydroponic production in general (Jones, 1997; Resh, 1998; Savvas and Passam, 2002).

\begin{tabular}{llll}
\hline $\begin{array}{l}\text { Units } \\
\text { To convert U.S. to SI, } \\
\text { multiply by }\end{array}$ & U.S. unit & SI unit & $\begin{array}{l}\text { To convert SI to U.S., } \\
\text { multiply by }\end{array}$ \\
\hline 29.5735 & $\mathrm{fl} \mathrm{oz}$ & $\mathrm{mL}$ & 0.0338 \\
0.3048 & $\mathrm{ft}$ & $\mathrm{m}$ & 3.2808 \\
0.0929 & $\mathrm{ft}^{2}$ & $\mathrm{~m}^{2}$ & 10.7639 \\
3.7854 & gal & $\mathrm{L}$ & 0.2642 \\
2.5400 & inch $(\mathrm{es})$ & $\mathrm{cm}^{2}$ & 0.3937 \\
6.4516 & inch & $\mathrm{cm}^{2}$ & 0.1550 \\
0.4536 & $\mathrm{lb}$ & $\mathrm{kg}$ & 2.2046 \\
28.3495 & $\mathrm{Oz}$ & $\mathrm{g}$ & 0.0353 \\
1 & $\mathrm{ppm}$ & $\mathrm{mg} \cdot \mathrm{L}^{-1}$ & 1 \\
$\left({ }^{\circ} \mathrm{F}-32\right) \div 1.8$ & ${ }^{\circ} \mathrm{F}$ & ${ }^{\circ} \mathrm{C}$ & $\left(1.8 \times{ }^{\circ} \mathrm{C}\right)+32$ \\
& & &
\end{tabular}




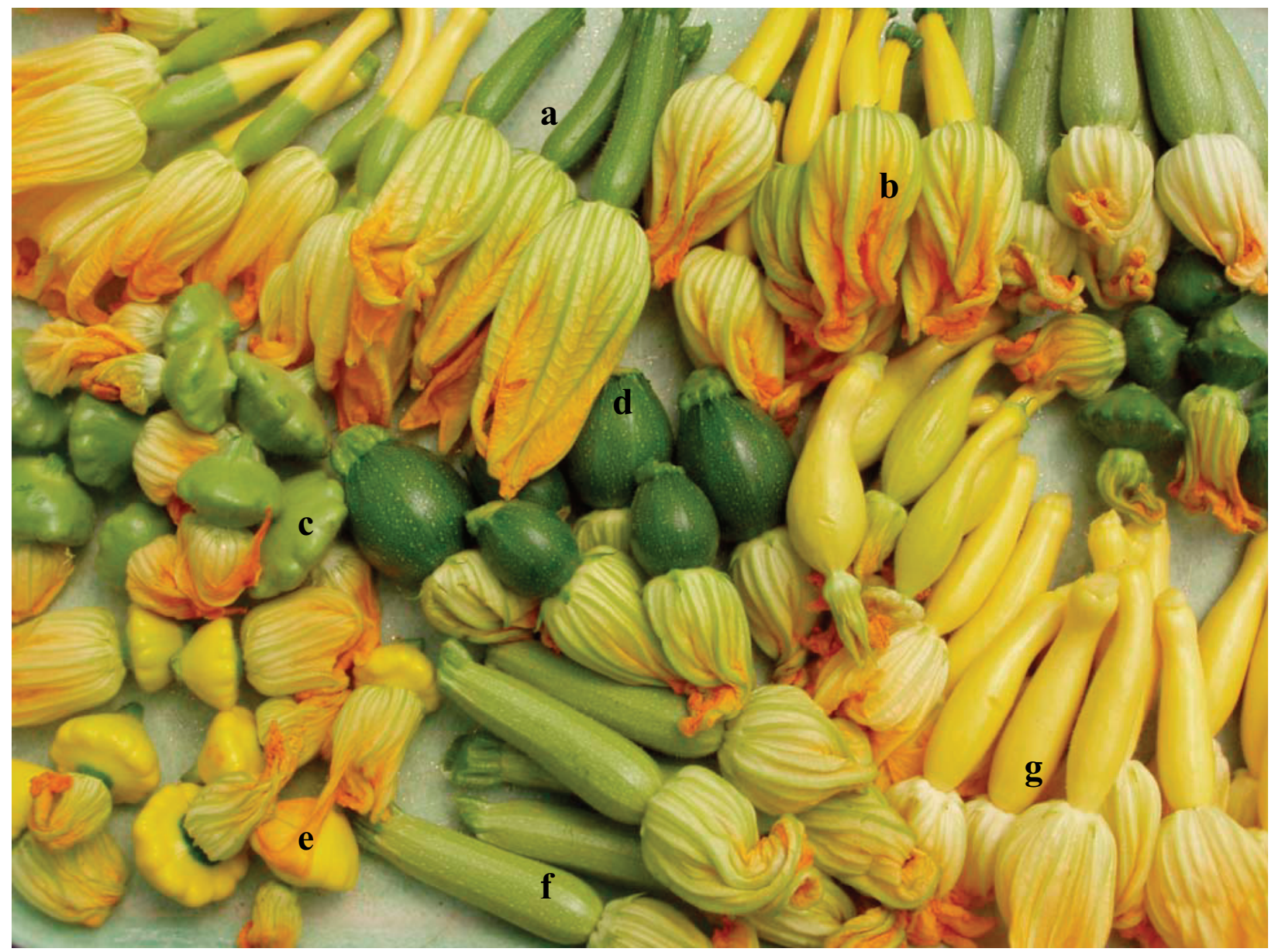

Fig. 1. Types of baby squash with blossoms attached can be marketed to high-end retail outlets: $a=$ green zucchini; $b=$ yellow zucchini; $c=$ light green, patty pan/scallop; $d=$ round zucchini; $e=$ yellow, patty pan/scallop; $\mathrm{f}=$ cousa; $\mathrm{g}=$ yellow summer.

Colla et al. (2004a, 2004b) describe how to measure mineral nutrition of zucchini squash plants grown in perlite, but do not describe production or harvest methods as their focus was placed on modeling, dry weights, and mineral composition. It is unknown whether squash could be produced hydroponically using soilless media in a passively ventilated structure in Florida and harvested specifically for the baby squash market. There have been no cultivars selected for baby squash production and marketed as such via U.S. seed distributors and only a few squash cultivars are marketed for greenhouse production. The objective of this study was to identify squash cultivars suitable for the baby squash market that could be successfully grown in a greenhouse using hydroponic and integrated pest management strategies.

\section{Materials and methods}

Squash types evaluated included green and yellow zucchini, straight and crookneck yellow summer, patty pan/scallop, and cousa types (Fig. 1, Table 1). Cousa is a middle-eastern type squash, in which "cousa" means "squash" in Arabic. Only 'Bareket,' 'Goldy' and 'HA-187' were listed for tunnel or greenhouse production. 'Seneca Supreme' and 'Revenue' were not available in Jan. 2004 when the second trial began; however, 'Revenue' was substituted with 'Hurricane' by the distributor. On 23 Jan. 2003 and 24 Jan. 2004, seeds from each cultivar were sown in Styrofoam trays ( 128 cell count, Todd Planter Flats; Speedling, Bushnell, Fla.) filled with a mix of 3 parts sphagnum peat: 2 parts vermiculite (by volume). Transplants were grown in growth chambers (model E15; Coviron, Winnepeg, Man., Canada) at 25 ${ }^{\circ} \mathrm{C}$ constant temperature and a 14 -h photoperiod for 3 weeks. Transplants were irrigated every other day with $20 \mathrm{~N}-8.7 \mathrm{P}-16.6 \mathrm{~K}$ fertilizer solution to provide $100 \mathrm{mg} \cdot \mathrm{L}^{-1}$ nitrogen $(\mathrm{N})$, $50 \mathrm{mg} \cdot \mathrm{L}^{-1}$ phosphorus $(\mathrm{P}), 80 \mathrm{mg} \cdot \mathrm{L}^{-1}$ potassium $(\mathrm{K})$, and micronutrient concentrations of $0.2 \mathrm{mg} \cdot \mathrm{L}^{-1}$ boron $(\mathrm{B})$, $0.5 \mathrm{mg} \cdot \mathrm{L}^{-1}$ copper $(\mathrm{Cu}), 0.1 \mathrm{mg} \cdot \mathrm{L}^{-1}$ iron $(\mathrm{Fe}), 5 \mathrm{mg} \cdot \mathrm{L}^{-1}$ magnesium $(\mathrm{Mg})$, $0.5 \mathrm{mg} \cdot \mathrm{L}^{-1}$ manganese $(\mathrm{Mn}), 0.005$ $\mathrm{mg} \cdot \mathrm{L}^{-1}$ molybdenum $(\mathrm{Mo})$, and 0.005 $\mathrm{mg} \cdot \mathrm{L}^{-1}$ zinc $(\mathrm{Zn})$ (Peters 20-20-20 Professional All Purpose Plant Food; Spectrum Group, St. Louis).

In both seasons, the experiments were conducted in passively ventilated high-roof sawtooth-type greenhouses (Top Greenhouses Ltd., Rosh Ha'ayin, Israel). In 2003, the greenhouse was located at the Horticultural Sciences Department Protected Agriculture Project, part of the University of Florida Horticultural Research Unit in Gainesville. The sidewalls were $3.7 \mathrm{~m}$ high. A 1-m-tall roof vent was located at $8-\mathrm{m}$ height. The roof was covered with double-layer, $150-\mu \mathrm{m}$, antifog, polyethylene plastic (Ginegar Plastic Products Ltd., Kibbutz Ginegar, Israel). In 2004, a new greenhouse was constructed at the Plant Science 
Table 1. Squash cultivars evaluated for hydroponic "baby" squash production in a passively ventilated greenhouse in Florida using soilless media.

\begin{tabular}{|c|c|c|c|}
\hline Type & Cultivar name & Description & Seed company \\
\hline Zucchini $^{\mathrm{y}}$ & $\begin{array}{l}\text { Bareket } \\
\text { Eight Ball } \\
\text { Gold Rush } \\
\text { Goldy } \\
\text { Hurricane } \\
\text { Sebring } \\
\text { Revenue } \\
\text { Raven }\end{array}$ & $\begin{array}{l}\text { Dark green } \\
\text { Round, green } \\
\text { Deep yellow } \\
\text { Yellow } \\
\text { Medium green } \\
\text { Yellow, PMR }{ }^{x} \\
\text { Medium green } \\
\text { Dark green }\end{array}$ & $\begin{array}{l}\text { Hazera Genetics } \\
\text { Hollar Seeds } \\
\text { Johnny's Selected Seeds } \\
\text { Hazera Genetics } \\
\text { Nunhems USA } \\
\text { Hollar Seeds } \\
\text { Johnny's Selected Seeds } \\
\text { Johnny's Selected Seeds }\end{array}$ \\
\hline Yellow summer & $\begin{array}{l}\text { Seneca Supreme } \\
\text { Sunray } \\
\text { Supersett } \\
\text { Yellow Crookneck } \\
\text { Zephyr }\end{array}$ & $\begin{array}{l}\text { Straightneck } \\
\text { Straightneck } \\
\text { Crookneck } \\
\text { Crookneck } \\
\text { Green blossom end, } \\
\quad \text { straightneck }\end{array}$ & $\begin{array}{l}\text { Johnny's Selected Seeds } \\
\text { Johnny's Selected Seeds } \\
\text { Johnny's Selected Seeds } \\
\text { Johnny's Selected Seeds } \\
\text { Johnny's Selected Seeds }\end{array}$ \\
\hline $\begin{array}{l}\text { Patty pan } \\
\text { /scallop }\end{array}$ & $\begin{array}{l}\text { Butter Scallop } \\
\text { Patty Green Tint } \\
\text { Starship } \\
\text { Sunburst }\end{array}$ & $\begin{array}{l}\text { Pale yellow } \\
\text { Light green } \\
\text { Dark green } \\
\text { Deep yellow }\end{array}$ & $\begin{array}{l}\text { Johnny's Selected Seeds } \\
\text { Johnny's Selected Seeds } \\
\text { Johnny's Selected Seeds } \\
\text { Johnny's Selected Seeds }\end{array}$ \\
\hline Cousa & $\begin{array}{l}\text { HA-187 } \\
\text { Magda }\end{array}$ & $\begin{array}{l}\text { Mottled green } \\
\text { Pale green }\end{array}$ & $\begin{array}{l}\text { Hazera Genetics } \\
\text { Johnny's Selected Seeds }\end{array}$ \\
\hline
\end{tabular}

${ }^{2}$ Hazera Genetics, Inc., El Segundo, Calif.; Hollar Seeds, Inc., Rocky Ford, Colo.; Johnny's Selected Seeds, Winslow, Maine; Nunhems USA, Parma, Idaho.

y'Revenue' was discontinued in 2003 and replaced with 'Hurricane'. 'Seneca Supreme' was not available for trial in 2004

xMR = powdery mildew resistant.

Research and Education Unit in Citra, Fla. The new design had a single-layer, 200- $\mu \mathrm{m}$, antifog, polyethylene plastic (Ginegar Plastic Products Ltd.) roof having a $1.6-\mathrm{m}$-tall vent located on the east side of each bay; the sidewalls were $4.5 \mathrm{~m}$ high. The new greenhouse consisted of five bays oriented for plant rows in a north-south configuration. Each bay was $6.4 \mathrm{~m}$ wide $\times$ $56 \mathrm{~m}$ long (Sierra; Top Greenhouses Ltd.). Although there were height and width differences between the two styles of greenhouses, the main difference was the location of the upper vent and roof covering (single or double plastic). The vents in the Gainesville greenhouse were located in the center of each bay, while the vents in the Citra greenhouse were located between bays. These differences were not expected to influence the results of the experiment. For both greenhouses, sidewalls and roof vents were covered with 0.6-mm screen (Klaymen Meteor Ltd., Petah-Tikva, Israel) to prevent insect movement into or out of the greenhouse.

Three-week-old transplants were planted on 14 Feb. 2003 and 15 Feb. 2004 into 3-gal, black polyethylene nursery pots (Lerio Co., Kissimmee, Fla.) filled with pine bark. The pine bark was screened by the manufacturer (Elixson Wood Products, Starke, Fla.) to a size less than $1 \times 1$ inch $^{2}$ (Shaw et al., 2004). Pots were drilled 1 inch from the bottom with four equidistant $1 / 4$-inch-diameter holes for drainage. Each plot consisted of four plants spaced 15 inches from center to center of each container and $4 \mathrm{ft}$ from center to center of each row (plant density $=2.2$ plants $\left./ \mathrm{m}^{2}\right)$. In 2003 , temperatures were measured every 15 min using thermocouples located both inside and outside the greenhouse and recorded by a datalogger (CR-10; Campbell Scientific, Logan, Utah). In 2004, temperature data from inside and outside the greenhouse was also measured and recorded (Galileo; Eldar Shany Technologies, Yad-Mordechay, Israel).

Squash plants were fertigated through individual pressure-compensating emitters (Netafim USA, Fresno, Calif.) at a flow rate of $33 \mathrm{~mL} \cdot \mathrm{min}^{-1}$. Fertilizer levels remained the same throughout the season at $120 \mathrm{mg} \cdot \mathrm{L}^{-1}$ $\mathrm{N}$ (from calcium nitrate and potassium nitrate), $50 \mathrm{mg} \cdot \mathrm{L}^{-1}$ (from phosphoric acid), $150 \mathrm{mg} \cdot \mathrm{L}^{-1} \mathrm{~K}$ (from potassium chloride and potassium nitrate), 135 $\mathrm{mg} \cdot \mathrm{L}^{-1} \mathrm{Ca}$ (from calcium nitrate), 50 $\mathrm{mg} \cdot \mathrm{L}^{-1} \mathrm{Mg}$ (from magnesium sulfate),
$65 \mathrm{mg} \cdot \mathrm{L}^{-1} \mathrm{~S}$ (from all sulfate sources listed here), $3 \mathrm{mg} \cdot \mathrm{L}^{-1} \mathrm{Fe}$ (from Sequestrene 330 ), $0.2 \mathrm{mg} \cdot \mathrm{L}^{-1} \mathrm{Cu}$ (from copper sulfate), $0.8 \mathrm{mg} \cdot \mathrm{L}^{-1} \mathrm{Mn}$ (from manganese sulfate), $0.3 \mathrm{mg} \cdot \mathrm{L}^{-1} \mathrm{Zn}$ (from zinc sulfate), $0.7 \mathrm{mg} \cdot \mathrm{L}^{-1} \mathrm{~B}$ (from Solubor), and $0.06 \mathrm{mg} \cdot \mathrm{L}^{-1} \mathrm{Mo}$ (from molybdenum sulfate). The $\mathrm{pH}$ of the final solution remained between 5.5 and 6.5 .

Each plant was individually trellised vertically on twine similar to that used for greenhouse cucumber production (Shaw et al., 2000). Since the stems of the squash plants were strong and more than 1 inch in diameter, plastic clips typically used in cucumber production were used only once, for the initial clip at the base of the plant to secure the squash plants to the twine. Above this point, horticulture twist ties were placed approximately every 6 inches to vertically secure the main stem of the squash plant. Laterals were removed from all cultivars to encourage indeterminate growth.

Bumble bees (Bombusimpatiens; Koppert Biologicals, Romulus, Mich.) were used for pollination and their presence in the greenhouse limited pest control measures. Arthropod pests were controlled with biological agents. Green peach aphids (Myzus persicae) were controlled using lady beetle larvae (Hippodamia convergens; Entomos, Gainesville, Fla.) and parasitic wasps (Aphidius colemani; IPM Laboratories, Locke, N.Y.). The lady beetle larvae were only released at the Gainesville location. Few two-spotted spider mites (Tetranychus urticae) and thrips (Frankliniella occidentalis) were found during each season; however, both were controlled by releasing minute pirate bugs (Orius insidious; Entomos and Koppert Biologicals) and predatory mites (Ambelysiuscucumeris, Koppert Biologicals). Predatory mites (Neoseiulus californicus; Biotactics, Perris, Calif.) were also released to control two-spotted spider mites. Powdery mildew (Sphaerotheca fuliginea) was controlled using myclobutanil (Nova; Rohm \& Haas Co., Philadelphia), azoxystrobin (Quadris; Zeneca Agricultural Products, Wilmington, Del.) and sulfur dust. In 2003, myclobutanil was sprayed once 4 weeks after transplanting and sulfur dust was applied to non-experimental plants once perweek beginning 10 weeks after transplanting. Applications of azoxystrobin were made two times in 2004 in rotation 
with two applications of myclobutanil beginning 2 weeks after transplanting. In 2004, a fungicide compatible with biological control mechanisms containing $27 \%$ hydrogen dioxide (Oxidate, Biosafe Systems, Glastonbury, Conn.), was used bi-weekly beginning 6 weeks after transplanting.

Plants were harvested two or three times per week. There were a total of 28 harvests in 2003 beginning on 10 Mar. and ending on 15 May, and 15 harvests from 11 Mar. until 29 Apr. in 2004. Fruit were harvested per plot and graded by size and shape. USDA grade standards for baby squash have not been published; however, baby squash at retail markets weighs approximately 20-30 g per fruit (Schmidt, 2003). Based on size and weight of baby squash sold in local supermarkets, zucchini, yellow summer, and cousa-types were graded as "baby" fruit if they were 3 to 4 inches in length. Fruit sizes up to 8 inches in length and uniformly shaped were graded fancy; other marketable fruit were graded No.l; and all nonmarketable fruit were culled. Non-marketable fruit were characterized as misshapen, damaged, or having poor color development. Patty pan/scallop types and the round zucchini 'Eight Ball' were considered "baby" size if they were 1 to 1.5 inch diameter. Fruit that were 1.5 to 3 inches in diameter and uniformly shaped were graded fancy; other marketable fruit were graded No. 1; and all non-marketable fruit were discarded as culls. Total marketable fruit was the combined total of baby, fancy, and No. 1 grade categories.

Near the end of both seasons, mature squash plants were rated for powdery mildew incidence. Plants were visually rated on 9 May 2003 and 16 Apr. 2004. Each plot was rated independently on a 1 to 5 scale, where $\mathrm{l}=$ leaves show no powdery mildew; $2=25 \%$ of leaves covered with powdery mildew; $3=50 \%$ coverage; $4=$ $75 \%$ coverage; and $5=100 \%$ or the most severe coverage with powdery mildew.

The experiments were a randomized complete-block design with three

Table 2. Yield variables per plant for selected squash cultivars grown hydroponically durng Spring 2003 in Gainesville, Fla.

\begin{tabular}{|c|c|c|c|c|c|c|c|}
\hline ltivarar,y & $\begin{array}{l}\text { Baby } \\
\text { fruit } \\
\text { (no.) }\end{array}$ & $\begin{array}{l}\text { Baby } \\
\text { fruit } \\
\text { wt }(g)^{x}\end{array}$ & $\begin{array}{l}\text { Fancy } \\
\text { fruit } \\
\text { (no.) }\end{array}$ & $\begin{array}{c}\text { Fancy } \\
\text { fruit } \\
\text { wt }(g)^{x}\end{array}$ & $\begin{array}{c}\text { Culls } \\
\text { (no.) }\end{array}$ & $\begin{array}{l}\text { Marketable } \\
\text { fruit } \\
\text { (no.) }\end{array}$ & $\begin{array}{c}\text { Marketable } \\
\text { fruit wt } \\
\text { (kg/plant })^{x}\end{array}$ \\
\hline
\end{tabular}

\begin{tabular}{|c|c|c|c|c|c|c|c|}
\hline $\begin{array}{l}\text { Zucchini } \\
\text { Bareket }\end{array}$ & 16 & 409 & 4 & 204 & $<1$ & 22 & 0.7 \\
\hline Eight Ball & 20 & 546 & 7 & 437 & $<1$ & 28 & 1.0 \\
\hline Gold Rush & 21 & 435 & 4 & 156 & $<1$ & 27 & 0.7 \\
\hline Goldy & 19 & 420 & 5 & 188 & $<1$ & 25 & 0.7 \\
\hline Raven & 25 & 631 & 11 & 592 & $<1$ & 34 & 1.3 \\
\hline Revenue & 22 & 679 & 17 & 1027 & 3 & 41 & 1.9 \\
\hline Sebring & 17 & 379 & 5 & 203 & $<1$ & 23 & 0.6 \\
\hline $\mathrm{LSD}_{(0.05)}$ & 4 & 120 & 2 & 113 & NS & 5 & 0.2 \\
\hline \multicolumn{8}{|l|}{ Yellow-summer } \\
\hline Seneca Supreme & 48 & 1015 & 22 & 870 & 1 & 74 & 2.0 \\
\hline Sunray & 40 & 843 & 16 & 655 & 2 & 59 & 1.6 \\
\hline Supersett & 43 & 850 & 15 & 593 & 4 & 59 & 1.5 \\
\hline Yellow Crookneck & 42 & 820 & 14 & 525 & 17 & 66 & 1.6 \\
\hline Zephyr & 27 & 588 & 14 & 674 & 3 & 48 & 1.5 \\
\hline $\operatorname{LSD}_{(0.05)}$ & 13 & 247 & NS & NS & 9 & NS & NS \\
\hline \multicolumn{8}{|l|}{ Patty pan/scallop } \\
\hline Butter Scallop & 51 & 961 & 26 & 1049 & $<2$ & 80 & 2.1 \\
\hline Patty Green Tint & 50 & 1050 & 26 & 1147 & $<2$ & 83 & 2.4 \\
\hline Starship & 51 & 1022 & 17 & 683 & $<1$ & 70 & 1.8 \\
\hline Sunburst & 67 & 1229 & 15 & 563 & $<3$ & 85 & 1.9 \\
\hline $\operatorname{LSD}_{(0.05)}$ & 9 & NS & 7 & 224 & NS & NS & 0.4 \\
\hline \multicolumn{8}{|l|}{ Cousa } \\
\hline HA-187 & 34 & 1005 & 13 & 739 & $<1$ & 47 & 1.8 \\
\hline Magda & 27 & 838 & 17 & 983 & $<1$ & 44 & 1.8 \\
\hline Significance & * & NS & NS & NS & NS & NS & NS \\
\hline
\end{tabular}

Data were analyzed within cultivar-type and means were separated using least significant difference (LSD) at the $5 \%$ level. s, *Nonsignificant or significant at $P \leqq 0.05$, respectively.

Yields are an accumulation of 28 harvests. Plants were grown from 14 Feb. to 15 May 2003 in Gainesville, Fla. $\mathrm{g}=0.0353 \mathrm{oz} ; \mathrm{l} \mathrm{kg}=2.2046 \mathrm{lb}$.

replications. All cultivar types were randomized throughout each block. Each season was analyzed separately due to significant interactions between environment (season) and cultivar. Data were analyzed within cultivar type using the statistical software package SAS (SAS Institute, Cary, N.C.) and means were separated using least significant difference at the $5 \%$ level.

\section{Results and discussion}

Minimum temperature outside the greenhouse in 2003 was $36^{\circ} \mathrm{F}$ and maximum was $94^{\circ} \mathrm{F}$; average outside temperature for the season was 67 ${ }^{\circ} \mathrm{F}$. Minimum temperature inside the greenhouse was $56^{\circ} \mathrm{F}$ and the high temperature was $103^{\circ} \mathrm{F}$; average temperature inside the greenhouse for the 2003 season was $73^{\circ} \mathrm{F}$. The seasonal minimum and maximum temperature was less in 2004 (outside minimum 35 ${ }^{\circ} \mathrm{F}$ outside maximum $94^{\circ} \mathrm{F}$; inside minimum $55^{\circ} \mathrm{F}$ inside maximum $99{ }^{\circ} \mathrm{F}$ ), but the overall average temperatures both outside and inside the greenhouse were about $5^{\circ} \mathrm{F}$ warmer than 2003 at $72{ }^{\circ} \mathrm{F}$ and $78^{\circ} \mathrm{F}$, respectively.

The yellow and green zucchinitype cultivars Gold Rush, Raven, and Revenue produced significantly more baby fruit per plant than 'Bareket', 'Eight Ball', 'Goldy', and 'Sebring' in 2003 (Table 2). In 2004, 'Hurricane' and 'Eight Ball' yielded the greatest number of baby fruit per plant among the zucchini types (Table 3 ). While the cultivars Gold Rush and Raven were among the higher yielding zucchini-type cultivars in 2003 , both were among the lower yielding cultivars in 2004. In 2003, the majority of baby squash harvested from 'Gold Rush' and 'Raven' occurred after the 10th harvest; therefore, the shortened season during 2004 may have contributed to the lower production.

In 2003 there was a significant difference among the yellow-summer types for number of baby fruit per plant. 'Zephyr' produced a significantly lower 
Table 3. Yield variables per plant for selected squash cultivars grown hydroponically during Spring 2004 in Citra, Fla.

\begin{tabular}{|c|c|c|c|c|c|c|c|}
\hline Cultivar $^{z, y}$ & $\begin{array}{l}\text { Baby } \\
\text { fruit } \\
\text { (no.) }\end{array}$ & $\begin{array}{l}\text { Baby } \\
\text { fruit } \\
\text { wt }(g)^{x}\end{array}$ & $\begin{array}{l}\text { Fancy } \\
\text { fruit } \\
\text { (no.) }\end{array}$ & $\begin{array}{c}\text { Fancy } \\
\text { fruit } \\
\text { wt }(g)^{x}\end{array}$ & $\begin{array}{c}\text { Culls } \\
\text { (no.) }\end{array}$ & $\begin{array}{c}\text { Marketable } \\
\text { fruit } \\
\text { (no.) }\end{array}$ & $\begin{array}{c}\text { Marketable } \\
\text { fruit wt } \\
(\mathrm{kg} / \text { plant })^{\mathrm{x}}\end{array}$ \\
\hline \multicolumn{8}{|l|}{ Zucchini } \\
\hline Bareket & 8 & 195 & 2 & 80 & $<1$ & 10 & 0.3 \\
\hline Eight Ball & 15 & 376 & 3 & 285 & 0 & 18 & 0.7 \\
\hline Gold Rush & 10 & 205 & 2 & 102 & 0 & 13 & 0.3 \\
\hline Goldy & 14 & 304 & 4 & 216 & 0 & 19 & 0.6 \\
\hline Hurricane & 17 & 403 & 6 & 336 & $<1$ & 24 & 0.8 \\
\hline Raven & 14 & 352 & 6 & 350 & 0 & 21 & 0.8 \\
\hline Sebring & 13 & 290 & 3 & 166 & 0 & 17 & 0.5 \\
\hline $\operatorname{LSD}_{(0.05)}$ & 2 & 57 & 2 & 113 & NS & 3 & 0.1 \\
\hline \multicolumn{8}{|l|}{ Yellow-summer } \\
\hline Sunray & 24 & 456 & 9 & 404 & 1 & 34 & 1.0 \\
\hline Supersett & 21 & 392 & 7 & 294 & 3 & 29 & 0.7 \\
\hline Yellow Crookneck & 18 & 308 & 6 & 227 & 11 & 27 & 0.7 \\
\hline Zephyr & 17 & 318 & 9 & 433 & $<1$ & 30 & 1.0 \\
\hline $\operatorname{LSD}_{(0.05)}$ & NS & 105 & NS & NS & 2 & NS & 0.2 \\
\hline \multicolumn{8}{|l|}{ Patty pan/scallop } \\
\hline Butter Scallop & 25 & 480 & 8 & 427 & 2 & 36 & 1.2 \\
\hline Patty Green Tint & 22 & 446 & 5 & 259 & $<1$ & 29 & 0.9 \\
\hline Starship & 25 & 513 & 6 & 329 & $<1$ & 32 & 0.9 \\
\hline Sunburst & 39 & 1033 & 3 & 215 & 2 & 42 & 1.3 \\
\hline $\mathrm{LSD}_{(0.05)}$ & 7 & NS & 2 & 100 & NS & NS & NS \\
\hline \multicolumn{8}{|l|}{ Cousa } \\
\hline HA-187 & 21 & 501 & 5 & 284 & 1 & 27 & 0.8 \\
\hline Magda & 18 & 484 & 9 & 519 & $<1$ & 28 & 1.1 \\
\hline Significance & NS & NS & NS & * & * & NS & $*$ \\
\hline
\end{tabular}

${ }^{2}$ Data were analyzed within cultivar-type and means were separated using least significant difference (LSD) at the 5\% level. Ns, ${ }^{*}$ Nonsignificant or significant at $P \leq 0.05$.

yields are an accumulation of 15 harvests. Plants were grown from 15 Feb. to 29 Apr. 2004 in Citra, Fla.

${ }^{\mathrm{x}} \mathrm{l} \mathrm{g}=0.0353 \mathrm{oz} ; \mathrm{l} \mathrm{kg}=2.2046 \mathrm{lb}$.

number of baby fruit at 27 compared to an average of 43 between 'Seneca Supreme', 'Sunray', 'Supersett', and 'Yellow Crookneck'. There was no difference among the same cultivars in 2004 (excluding 'Seneca Supreme', which was not grown), where the average number of baby squash was 20 fruit/plant.

In both seasons, the patty pan/ scallop-type squash cultivars produced the greatest number of baby fruit of all cultivar types grown (Tables 2 and 3 ). 'Sunburst' produced significantly more baby fruit per plant than the other three cultivars with 67 and 39 fruit per plant, respectively, for 2003 and 2004. The other patty pan/scallop-type cultivars ('Butter Scallop', 'Patty Green Tint', and 'Starship') produced on average, 50 and 24 fruit per plant, respectively, for each season. The cousa-type cultivar HA-187 produced significantly more baby fruit per plant than 'Magda' in 2003; however, there was no difference between the two cultivars in 2004 (average 20).
'Revenue' and 'Raven' produced the greatest weight of baby squash per plant for the zucchini-type cultivars in 2003; however, in 2004, the cultivars Eight Ball, Hurricane, and Raven produced the greatest weight of baby squash per plant (Table 2 and $3)$. In 2003 , the yellow-summer-type 'Zephyr' produced a significantly lower weight of baby fruit, $588 \mathrm{~g} /$ plant, than the four other cultivars, which averaged $882 \mathrm{~g}$ /plant. In 2004, 'Sunray' and 'Supersett' produced the greatest weight of baby fruit, an average of 424 $\mathrm{g} /$ plant. In both seasons, weight of baby fruit per plant was not different among the patty pan/scallop or cousa cultivars. The patty pan/scallop-type cultivars averaged 1065 and $618 \mathrm{~g} /$ plant, respectively, for 2003 and 2004; the cousa types averaged 922 and 492 $\mathrm{g} /$ plant, respectively, for each season. Baby squash for all fruit types were harvested and graded by the size recommended for packaging, and average baby fruit weight of all squash cultivars grown was 18 to $30 \mathrm{~g}$ /fruit.
Number and weight of fancy fruit per plant were reported to show the potential losses of baby fruit when harvesting was not done every other day (Tables 2 and 3 ). Such events occurred on a Monday harvest after the weekend. In 2003, 'Revenue' produced significantly more fancy fruit per plant than the other six zucchini-type cultivars, which may suggest this cultivar needs to be harvested on a daily basis rather than every other day for the baby squash market. 'Revenue' was not produced in 2004 since seed was not available, but its replacement, 'Hurricane', also produced the greatest number of fancy fruit for the zucchini-type cultivars. 'Revenue' yielded 17 fancy fruit per plant even though the primary goal of the research herein was to harvest squash at $10 \mathrm{~cm}$ in length. This was comparable to the yields of Rouphael et al. (2004), who grew the zucchini cv. Aphrodite in a passively ventilated polyethylene-covered greenhouse using soilless media (cocofiber, perlite, and pumice). In their study, marketable fruit were harvested when fruit were greater than $12 \mathrm{~cm}$ in length; a size comparable to USDA fancy grade fruit. Their total yields were 20 fruit/plant with an average fruit weight of $110 \mathrm{~g}$. Thus, 'Revenue' may be used for both the baby squash and fancy fruit markets.

There were no significant differences among the yellow-summer-type cultivars for number or weight of fancy fruit in either 2003 or 2004 (Tables 2 and 3 ). In 2003, there were no differences among the cousa types for yield of fancy fruit; however, in 2004, 'Madga' produced a greater weight of fancy fruit than 'HA-187'. In 2003, both 'Butter Scallop' and 'Patty Green Tint' produced significantly more numbers and weight of fancy fruit than the other patty pan/scallop cultivars Starship and Sunburst. However, in 2004, 'Butter Scallop' produced the greatest number of fancy fruit per plant, but weight of fancy fruit was not greater than 'Patty Green Tint' and 'Starship'. For growers who do not have a market for fancy fruit, it is recommended that all cultivar types grown be harvested 
daily in order to achieve higher baby fruit yields.

In both 2003 and 2004, culls were minimal for most squash cultivars evaluated (Table 2 and 3 ). However, during both seasons, 'Yellow Crookneck' produced many misshaped fruit or fruit that remained an immature green color when harvested at a small size and therefore could not be considered marketable. In 2003, in spite of the number of culls produced, 'Yellow Crookneck' remained one of the higher yielding cultivars.

Total marketable yield is the combined totals of baby, fancy, and No. 1 fruit grades (Tables 2 and 3). In 2003, 'Raven' and 'Revenue' produced the greatest number of marketable fruit of the zucchini-type squash, an average of 38 fruit/plant. 'Revenue' also produced the greatest weight of marketable fruit among the zucchini types at $1.9 \mathrm{~kg} /$ plant. In 2004, 'Hurricane' and 'Raven' produced the greatest number of marketable fruit of the zucchini-type squash, an average of 23 fruit/plant $(0.8 \mathrm{~kg})$. In both seasons, there were no significant differences among the yellow-summer, patty pan/scallop, and cousa-type cultivars for number of marketable fruit. In 2003, there were no significant differences among either the yellow-summer or cousatype cultivars for total marketable fruit weight; average was 1.6 and 1.8 $\mathrm{kg}$ /plant, respectively. However, in 2004 , the total marketable fruit weights of 'Sunray' and 'Zephyr' were greater than 'Supersett' and 'Yellow Crookneck', $1.0 \mathrm{~kg}$ / plant compared to 0.7 $\mathrm{kg} /$ plant. For the cousa-types, 'Madga' produced a greater total marketable fruit weight than 'HA-197'. While in 2003, both 'Butter Scallop' and 'Patty Green Tint' produced significantly greater marketable weight of fruit per plant than the other patty pan/scallop cultivars Starship and Sunburst, 2.3 vs. $1.8 \mathrm{~kg} /$ plant, respectively, there was no difference among the four cultivars in 2004 , an average of $1.1 \mathrm{~kg} /$ plant. In 2003 , the greatest marketable yield over all 18 cultivars was produced by the patty pan/scallop-type cultivar Patty Green Tint $(2.4 \mathrm{~kg})$. In 2004, of all 17 cultivars trialed, the patty pan/scallop-type cultivar Sunburst produced the greatest marketable yield with $1.3 \mathrm{~kg} /$ plant.

Powdery mildew appears to be a severe problem for greenhouse production of cucurbits in mild winter cli- mates (Shaw and Cantliffe, 2003). Preventative sprays of the fungicides myclobutanil and azoxystrobin were made in both seasons; however, within 4 to 6 weeks after transplanting, spores of powdery mildew, were noticed throughout the experiment. Fungicide applications could not be made adequately throughout the entire season due to plant height and leaf canopy density; thus, the disease was not properly controlled. Fungicides must be applied in an integrated pest management system so as to not harm beneficial insects (bees should be removed or covered during application).

Powdery mildew was the primary cause for terminating the crop in both 2003 and 2004. In both years, most cultivars were severely affected by the disease (Table 4). Based on the rating scale used, the cultivars that showed some resistance were the yellow zucchinitypes 'Gold Rush' and 'Sebring', and the green zucchini 'Hurricane'. 'Sebring' was the only cultivar used in this trial labeled as PM resistant (Table 1). The five yellow summer-type cultivars developed the same level of PM in 2003; however, 'Sunray' was rated with less powdery mildew than 'Supersett' in 2004. All the patty-pan/scallop types were highly susceptible to powdery mildew in both years. Both cousa-type cultivars were highly susceptible in 2003 , but 'Magda' was not as severely infected with the disease as 'HA-187' in 2004. Cultivars selected for trial were not selected for PM resistance, but for their unique fruit type. Having a disease-free greenhouse prior to planting and earlier applications with fungicides, as well as better coverage, may help prevent the disease. Copper sulfate-containing fungicides cannot be used in an integrated pest management system because of their detrimental effect on beneficial insects.
Table 4. Powdery mildew (PM) ratings for selected squash cultivars grown hydroponically during Spring 2003 and 2004.

2003 PM rating 2004 PM rating $(1-5 \text { scale })^{\mathrm{y}} \quad(1-5 \text { scale })^{\mathrm{y}}$

$\begin{array}{lll}\text { Zucchini } & & \\ \text { Bareket } & 3.7 & 3.0 \\ \text { Eight Ball } & 4.7 & 3.3 \\ \text { Gold Rush } & 1.7 & 2.0 \\ \text { Goldy } & 2.7 & 2.3 \\ \text { Hurricane } & --- & 1.3 \\ \text { Raven } & 4.7 & 2.3 \\ \text { Revenue } & 5.0 & --- \\ \text { Sebring } & 2.3 & 1.0 \\ \text { LSD }_{(0.05)} & 1.2 & 1.3\end{array}$

Yellow-summer

Seneca Supreme

3.7

1.7

3.3

2.3

Supersett

3.7

5.0

Zephyr

4.0

4.3

3.0

1.7

Patty pan/scallop

Patty Green Tint

3.3

3.7

3.7

4.7

4.3

3.3

3.3

3.7

NS

HA-187

3.0

4.0

4.0

2.3

NS

*

\begin{tabular}{l}
3.0 \\
3.3 \\
2.0 \\
.3 \\
.3 \\
2.3 \\
.- \\
.0 \\
.3 \\
\\
.- \\
2.3 \\
5.0 \\
4.3 \\
3.0 \\
1.7 \\
\\
3.7 \\
4.7 \\
3.3 \\
3.7 \\
NS \\
4.0 \\
\hline
\end{tabular}

Data were analyzed within cultivar-type and means were separated using a $1-5$ scale: $1=$ leaves show no powdery mildew; $2=25 \%$ leaves covered with powdery mildew; $3=50 \%$ coverage; $4=75 \%$ coverage; $5=$ $100 \%$ coverage with powdery mildew or most severe.

There is great potential for hydroponically grown baby squash; however, there is great need to have disease-resistant cultivars, especially for resistance to powdery mildew. Hydroponic greenhouse production of baby squash, especially under pesticide-free conditions, could increase market ability and potentially their value. The fruit are extremely clean, undamaged by wind or sand, more easily harvested on a daily basis, and should be in demand by both gourmet restaurant chefs and retail consumers. An economic analysis would be important to a greenhouse grower interested in producing and marketing baby squash. Based on the yield data obtained herein and using current wholesale prices of terminal markets (i.e., Miami, Fla.), this study will be published in a separate paper 
specific to the economics of hydroponic baby squash production.

Based on yield and fruit quality, these cultivars could be recommended for greenhouse production of baby squash: the green zucchini cultivars Hurricane and Raven, the yellow zucchini cultivars Gold Rush and Goldy, the yellow-summer cultivars Sunray, Seneca Supreme, and Supersett, and all four patty pan/scallop cultivars, not only due to their high yields, but also to their individual color patterns. Both of the cultivars Magda and HA187 are acceptable for cousa types. Other potential markets exist for edible squash blossoms, either attached or detached from the fruit, or simply the male flowers alone (Villalta et al., 2004). Sidnam (2004) stated that baby squash can be found in gourmet produce markets for $\$ 5$ to $\$ 6$ per pound. Currently, baby squash sell in regional supermarkets for approximately $\$ 3.49$ per 8-oz pack (Publix Supermarkets, Lakeland, Fla.). These fruit are grown in open-field culture in South and Central American countries, packaged, and air-freighted to the U.S. With the advantage of proximity to market and the potential for outstanding yields, greenhouse growers in the U.S. should have an advantage over producers of imported products.

\section{Literature cited}

Ali, M., U. Farooq, and Y.Y. Shih. 2003. Vegetable research and development in the ASEAN region: A guideline for setting priorities, p. 20-64. In: C.G. Kuo (ed.). Perspectives on ASEAN Cooperation in Vegetable Research and Development: Proc. Forum on the ASEAN-AVRDC Reg. Network on Veg. Res. and Dev. (AARNET). Assn. Southeast Asian Nations, Asian Veg. Res. and Dev. Ctr., Shanhua, Taiwan.
Associated Press. 2003. Veggies go baby bite size. 28 May 2004. <http://www. cbsnews.com/stories /2003/04/07/ health/main548176.shtml>.

Bachman, J. 2002. Specialty vegetables. ATTRA-National Sustainable Agricultural Information Service. CT 161, p. 1-8. 4 June 2004. <http://www.attra.ncat. org/attra-pub/specialtyveg.pdf>.

Cantliffe, D.J., N. Shaw, E. Jovicich, J.C. Rodriguez, I. Secker, and Z. Karchi. 2001. Passive ventilated high-roof greenhouse production of vegetables in a humid, mild winter climate. Acta Hort. 559:195-201.

Cantliffe, D.J., N.L. Shaw, and E. Jovicich. 2004. New vegetable crops for greenhouses in the southeastern United States. Acta Hort. 633:483-487.

Colla, G., Y. Rouphael, A.L. Molle, F. Saccardo, A. Graifenberg, and L. Giustiniani. 2004a. Influences of mineral nutrition on growth and elemental composition of hydroponically grown zucchini plants. Acta Hort. 644:399-407.

Colla, G., S. Fanasca, A.L. Molle, and F. Saccardo. 2004b. Use of hydroponic culture to assess the mineral nutrition of zucchini squash. Acta Hort. 644:457-462.

European and Mediterranean Plant Protection Organization (OEPP/EPPO). 2004. Cucurbits under protected cultivation. EPPO/OEPP Bul. 34(1):91-100.

Hochmuth, R.C. 2001. Greenhouse cucumber production-Florida greenhouse vegetable production handbook, Vol. 3. HS790. Florida Coop. Ext. Serv., Inst. Food Agr. Sci., Univ. of Florida.

Jones, J.B., Jr. 1997. Hydroponics. St. Lucie Press, Boca Raton, Fla.

Papadopoulos, A.D. 1994. Growing greenhouse seedless cucumbers in soil and soilless media. Agr. Agri-Food Canada. Ottawa, Ont. Publ. 1902/E.

Resh, H.M. 1998. Hydroponic food production. Woodbridge Press, Santa Barbara, Calif.
Rouphael, Y., G. Colla, A. Battistelli, S. Moscatello, E. Rea, S. Proietti, and F. Saccardo. 2004. Yield, water requirement, nutrient uptake and fruit quality of zucchini squash grown in soil and closed soilless culture. J. Hort. Sci. Biotechnol. 79(3):423-431.

Savvas, D. and H. Passam (eds.). 2002. Hydroponic production of vegetables and ornamentals. Embryo Publ., Athens, Greece.

Schmidt, A. 2003. Chef's book of formulas, yields \& sizes. 3rd ed. Wiley, Hoboken, N.J.

Shaw, N.L. and D.J. Cantliffe. 2003. Hydroponically produced mini-cucumber with improved powdery mildew resistance. Proc. Fla. State Hort. Soc. 116:58-62.

Shaw, N.L., D.J. Cantliffe, J.C. Rodriguez, B.S. Taylor, and D.M. Spencer. 2000. Beit alpha cucumber-An exciting new greenhouse crop. Proc. Fla. State Hort. Soc. 113:247-253.

Shaw, N.L., D.J. Cantliffe, J. Funes, and C. Shine III. 2004. Successful beit alpha cucumber production in the greenhouse using pine bark as an alternative soilless media. HortTechnology 14(2):289-294.

Sidnam, B. 2004. Garden sage: Start thinking about fall plantings-A summer treat. San Diego Union-Tribune, 18 July 2004. 25 Jan. 2005. <http://www.signonsandiego.com/uniontrib/20040718/ news_lhsl8sage.html>.

Stephens, D. 1996. Making a big world out of little vegetables. Amer. Veg. Grower. January:32, 34 .

Villalta, A.M., M. Ergun, A.D. Berry, N.L. Shaw, and S.A. Sargent. 2004. Quality changes of yellow summer squash blossoms (Cucurbita pepo) during storage. Acta Hort. 659:831-834.

Wolford, R. and D. Banks. 2004. Summer squash. 9 Dec. 2004. <http://www. urbanext.uiuc.edu/veggies/ssquash l. html>. 